\title{
Evidence for a permanent presence of schistosomiasis in Corsica, France, 2015
}

A Berry ${ }^{12}$, J Jillaux ${ }^{13}$, G Martin-Blondel ${ }^{24}$, J Boissier ${ }^{5}$, X Iriart ${ }^{12}$, B Marchou ${ }^{4}$, JF Magnaval ${ }^{1}$, P Delobel ${ }^{24}$

1. Service de Parasitologie-Mycologie, CHU Toulouse, Toulouse, France

2. Centre de Physiopathologie de Toulouse Purpan, INSERM UMR U1043, CNRS UMR 5282, Université de Toulouse, Toulouse, France

3. UMR 152, Université de Toulouse, Toulouse, France

4. Service des Maladies Infectieuses et Tropicales, CHU Toulouse, Toulouse, France

5. Université de Perpignan Via Domitia, IHPE UMR 5244, CNRS, IFREMER, Université de Montpellier, Perpignan, France

Correspondence: Antoine Berry (berry.a@chu-toulouse.fr)

Berry A, Fillaux J, Martin-Blondel G, Boissier J, Iriart X, Marchou B, Magnaval J, Delobel P. Evidence for a permanent presence of schistosomiasis in Corsica, France, 2015. Euro Surveill. 2016;21(1):pii=30100. DOI: http://dx.doi.org/10.2807/1560-7917.ES.2016.21.1.30100

Article submitted on 10 December 2015 / accepted on 05 January 2016 / published on 07 January 2016

We present a case of acute schistosomiasis acquired in Corsica after bathing in the Cavu River during the summer of 2015. The diagnosis was made following epidemiological, laboratory and serological assessments. After a previous outbreak of urogenital schistosomiasis during the summer of 2013, when more than 120 infections were diagnosed, this further case indicates transmission was still effective in 2015, thus suggesting a permanent presence of schistosomiasis in Corsica.

We report a case of schistosomiasis acquired in 2015 in Corsica, indicating that permanent transmission of this helminthiasis has been established on the island.

\section{Case description}

On 11 September 2015, a person in their 40s presented to the Consultation Board at the Infectious and Tropical Disease Department of Toulouse University Hospitals in France with a 15-day history of diffuse abdominal pain, headache and asthenia. The patient had no fever, and physical examination was unremarkable. In particular, the patient neither displayed any skin rash nor complained of pruritus. The white blood cell count was $6.0 \times 10^{9} / \mathrm{L}$, within the normal range $(4.0-$ $10.0 \times 10^{9}$ cells/L), but a blood eosinophilia $\left(3.2 \times 10^{9}\right.$ cells/L, normal range: $<0.5 \times 10^{9}$ cells/L) was observed by differential count. Biochemical tests of liver function found several abnormalities, namely a serum alanine aminotransferase level at $140 \mathrm{UI} / \mathrm{L}$ (normal range: 0-40 UI/L) and a gamma-glutamyl transferase level at $323 \mathrm{IU} / \mathrm{L}$ (normal range: 0-60 IU/L). Aspartate aminotransferase and total bilirubin levels were within the normal range. C-reactive protein was $11.7 \mathrm{mg} / \mathrm{L}$ (normal value: $<5 \mathrm{mg} / \mathrm{L})$.

By serology, the patient tested negative for cytomegalovirus, Epstein-Barr virus, hepatitis A, B and C, and Leptospira infections. Serodiagnostics of ascariasis, alveolar and cystic echinococcoses, fascioliasis, filariases, strongyloidiasis, trichinellosis and schistosomiasis were negative. The ELISA result for schistosomiasis (expressed as a ratio), although negative with a ratio of 0.770 , was close to the cut-off value of 1.0 . Schistosomiasis serology relied upon commercial ELISA kits (Bordier Affinity Products, Crissier, Switzerland) and indirect haemagglutination assay (IHA) (Fumouze Diagnostics, Levallois-Perret, France), which are both screening tests using Schistosoma mansoni extracts as antigen.

Because an aetiological diagnosis was not reached, the patient attended a further consultation on 24 September. The clinical picture remained unchanged, but blood eosinophilia decreased to $2 \times 10^{9}$ cells/L. By that time, specific laboratory examinations for urogenital schistosomiasis had been carried out because of the previous ELISA result and also because the patient informed us of their vacation in Corsica in summer 2015. Urinalysis was normal, and microscopic search for Schistosoma haematobium eggs remained negative. Serology was positive, with an ELISA ratio of 2.65 (cutoff: 1.0). The IHA result (expressed as a titre of dilution) was 160 (cut-off: 160). These results were checked by a commercial Western blot using a mixture of adult S. haematobium and S. mansoni antigens (SCHISTO II Western blot IgG, LDBIO Diagnostics, Lyon, France). Faintly positive bands were observed at $30 \mathrm{kDa}$ and 34 $\mathrm{kDa}$, a result which was specific for the Schistosoma genus.

On 15 October, the patient was asymptomatic, the eosinophil count had decreased to $0.5 \times 10^{9}$ cells $/ L$ and hepatic tests were back to normal values. The level of Schistosoma-specific antibodies, as measured by ELISA (ratio: 4.67) or IHA (titre: 320 ) had increased. 
Chronology of events and laboratory results

\begin{tabular}{|c|c|c|c|c|c|c|c|c|}
\hline Date (2015) & 30 July and 11 August & $\begin{array}{c}\text { From } 24 \\
\text { August }\end{array}$ & $\begin{array}{c}30 \\
\text { August }\end{array}$ & 7 September & $\stackrel{11}{\text { September }}$ & $\begin{array}{c}24 \\
\text { September }\end{array}$ & 15 October & 26 October \\
\hline Event & Bathing in the Cavu River & None & $\mathrm{MC}^{\mathrm{a}}$ & $M^{a}$ & MC & MC & MC & MC \\
\hline $\begin{array}{l}\text { Symptoms and } \\
\text { treatment }\end{array}$ & ND & $\begin{array}{l}\text { Abdominal } \\
\text { pain and } \\
\text { headache }\end{array}$ & Idem & Idem & Idem & $\begin{array}{l}\text { Decreasing } \\
\text { symptoms }\end{array}$ & $\begin{array}{c}\text { No } \\
\text { symptoms }\end{array}$ & $\begin{array}{c}\text { Praziquantel, } \\
40 \mathrm{mg} / \mathrm{kg} \\
\text { once }\end{array}$ \\
\hline $\begin{array}{l}\text { Eosinophil } \\
\text { count }(\mathrm{G} / \mathrm{L})\end{array}$ & ND & ND & 0.67 & 2.0 & 3.2 & 2.0 & 0.5 & NA \\
\hline $\begin{array}{l}\text { ELISA }^{\text {b }} \text { (cut-off: } \\
1.0)\end{array}$ & ND & ND & NA & NA & 0.77 & 2.65 & 4.67 & NA \\
\hline $\begin{array}{l}\text { IHAc (cut-off: } \\
160)\end{array}$ & ND & ND & NA & NA & Negative & 160 & 320 & NA \\
\hline $\begin{array}{l}\text { Western blot } \\
\text { (kDa bands) }\end{array}$ & ND & ND & NA & NA & Negative & $\begin{array}{l}30 / 34 \\
\text { (faint) }\end{array}$ & $30 / 34$ & NA \\
\hline $\begin{array}{l}\text { Urinary } \\
\text { sediment } \\
\text { examination }\end{array}$ & ND & ND & NA & NA & NA & NA & Normal & Normal \\
\hline $\begin{array}{l}\text { S. } \\
\text { haematobium } \\
\text { eggs in urine }\end{array}$ & ND & ND & NA & NA & NA & NA & Negative & Negative \\
\hline
\end{tabular}

ELISA: enzyme-linked immunosorbent assay; IHA: indirect haemagglutination assay; NA: not available; ND: not done.

a Medical consultations outside the Department of Infectious and Tropical Diseases.

${ }^{b}$ ELISA using extracts from adult worms and eggs of Schistosoma mansoni (Bordier Affinity Products, Crissier, Switzerland).

'Indirect haemagglutination using S. mansoni adult worm extracts (Fumouze Diagnostics, Levallois-Perret, France).

${ }^{d}$ Western blot using extracts from adult S. haematobium/S. mansoni worms (LDBIO Diagnostics, Lyon, France). Detection of genus-specific bands.

At that point, the Western blot result was clearly positive, with two sharp bands at 30 and $34 \mathrm{kDa}$. Results of immunodiagnoses for other helminthiases (see above) remained negative.

On 26 October, the patient attended the Consultation Board for the last time and received a single $40 \mathrm{mg} / \mathrm{kg}$ dose of praziquantel. Microscopic examination of the sediment from the whole-morning micturition failed again to find any S. haematobium eggs.

The course of clinical signs and laboratory results is displayed in the Table.

During the last consultation, the patient reported bathing twice for more than one hour in the Cavu River on 30 July and 11 August 2015. The patient had not been bathing in other rivers in Corsica and had no previous history of staying in or travelling to any classic or usual endemic area for schistosomiasis.

The patient's family (four persons) had also been bathing in the Cavu River at the same time, but for a shorter time. Three had unremarkable laboratory results and one child had discrepant immunodiagnostic results for schistosomiasis with a positive ELISA (ratio: 1.53), a negative IHA (titre: 80 ) and a negative Western blot (performed on 26 October). Because of the unclear result, this child was treated with a single dose of praziquantel $(40 \mathrm{mg} / \mathrm{kg})$ and serology will be repeated three months later to confirm or exclude the diagnosis of schistosomiasis.

\section{Discussion}

Here we present a case of schistosomiasis very probably acquired through bathing in the Cavu River in Corsica in summer 2015. Although microscopical examination of the patient's urine failed to find S. haematobium eggs, the combination of clinical symptoms, a transient blood eosinophilia, positive results from three immunodiagnostic tests (two screening tests and one confirmatory test), along with the kinetics of anti-Schistosoma antibodies consistent with a seroconversion, presented a syndrome that was diagnosed as acute schistosomiasis. Furthermore, the patient did not report any history of bathing in other Rivers in Corsica or staying in or travelling to classic or usual endemic areas for schistosomiasis. Previously, an outbreak of urogenital schistosomiasis had been identified in connection with bathing in the same river during the summer of 2013 [1-5]. That no schistosomiasis infections were observed in the 2014 summer is probably due to the fact that the French authorities prohibited bathing in the Cavu River. This ban had been lifted by spring 2015 .

In 1966, Jean-Marie Doby, a French parasitologist, stated that Corsica met all the requirements for permanent transmission of urogenital schistosomiasis [6]. This became true nearly 50 years later when more than 120 cases of autochthonous schistosomiasis were 
diagnosed in France. All these infections were acquired after bathing in the Cavu River in southern Corsica and all were consistent with an infection during summer 2013 [1-5]. Transmission occurring before and after 2013 has been reported in two articles $[7,8]$. However, in both series, the diagnosis of schistosomiasis was questionable in our view, since it relied only upon conflicting serological results that were not followed up by a second test [9].

The present case who got infected in summer 2015 raises the question about the parasite's origin. The hypothesis of an aetiological link between the 2013 outbreak and the present case is attractive, although the lack of molecular evidence makes this assumption purely speculative. If true, the parasite would have survived either in an infected human or in the environment, in an intermediate mollusk host or a domestic or wild mammal definitive host.

The hypothesis of an independent introduction to the same river by an infected person coming from an endemic country, appears unlikely. However, the hypothesis of an environmental reservoir also appears unlikely. The time between the first contaminations in August 2013 and the present case was ca 24 months, including two winter seasons. Although nothing is known of the persistence of Schistosoma in cold conditions, such a period seems too long for the parasite to persist inside a mollusk host. Indeed, mollusks from the Cavu River that were experimentally infected by low inoculums of the Corsica strain of S. haematobium survived up to nine months in laboratory conditions $\left(25^{\circ} \mathrm{C}\right.$ constant temperature and ad libitum feeding). Moreover, since the Corsica strain is a hybrid form between human and bovine Schistosoma [10], potential animal reservoir hosts have been screened for Schistosoma infections. Ruminants (cows and goats) that grazed along the Cavu River tested negative for Schistosoma infection. Trapped rodents were also found free of blood flukes (data not shown).

The most likely hypothesis is that people who were initially infected in 2013 in the Cavu River re-seeded the waterway with blood flukes by urinating. This suggests that the wide-scale screening of more than 37,000 people in France [6] did not identify all human carriers shedding Schistosoma eggs. If that is the case, it is possible that schistosomiasis could be spread to other rivers in Corsica, and to all of southern Europe (continental France, Spain, Portugal, Italy, and Greece) where the snail intermediate host is present.

\section{Conclusion}

Permanent transmission of schistosomiasis in Corsica is a new challenge for the French and European health authorities, whose goals should be to improve the effectiveness of screening and consecutive treatment of the infected, and to list any new case of autochthonous schistosomiasis. These measures will improve control of the initial focus and may prevent a possible expansion of urogenital schistosomiasis across southern Europe. General practitioners and specialists should become aware that schistosomiasis is not exclusively a tropical disease but has to be added to other possible aetiologies of blood eosinophilia or haematuria, even in patients without a history of staying in Africa or the Middle East.

Physicians should also be reminded that the pre-patent period of the infection, during which serological tests are still negative, may last formore than three months [11] and that seroconversion such as assessed by Western blot could be delayed when compared with the results provided by ELISA or IHA screening tests.

\section{Conflict of interest}

None declared.

\section{Authors' contributions}

All authors were involved in the case investigation and contributed to the manuscript. This included expertise in infectious diseases (GMB, BM, PD), parasitology ( $A B, J F, J B$, JFM, $X I)$, diagnosis ( $A B, J F, X I, P D)$, and drafting the manuscript $(A B, J F, J B, J F M, P D)$.

\section{References}

1. Holtfreter MC, Moné H, Müller-Stöver I, Mouahid G, Richter J. Schistosoma haematobium infections acquired in Corsica, France, August 2013. Euro Surveill. 2014;19(22):20821. DOI: 10.2807/1560-7917.ES2014.19.22.20821 PMID: 24925456

2. Berry A, Moné H, Iriart X, Mouahid G, Aboo O, Boissier J, et al. Schistosomiasis haematobium, Corsica, France. Emerg Infect Dis. 2014;20(9):1595-7. DOI: 10.3201/eid2009.140928 PMID: 25153697

3. Brunet J, Pfaff AW, Hansmann Y, Gregorowicz G, Pesson B, Abou-Bacar A, et al. An unusual case of hematuria in a French family returning from Corsica. Int J Infect Dis. 2015;31:59-60. DOI: 10.1016/j.ijid.2014.10.024 PMID: 25461660

4. Patard PM, Debuisson C, Mouttalib S, Berry A, Garnier A, Galinier P, et al. [Urinary schistosomiasis contracted in a child in Corsica]. Arch Pediatr. 2015;22(3):327-8. DOI: 10.1016/j. arcped.2014.11.023 PMID: 25617056

5. Haut Conseil de la santé publique (HCSP). Avis relatif à la surveillance nationale des cas autochtones de bilharziose urogénitale. [Notice regarding national surveillance of autochthonous cases of urogenital schistosomiasis]. Paris: HCSP; 2015. French. Available from: http://www.hcsp.fr/ explore.cgi/avisrapportsdomaine?clefr $=525$

6. Doby JM, Rault B, Deblock S, Chabaud A. [Snails and bilharziasis in Corsica. Distribution, frequency and biology of "Bulinus truncatus"]. Ann Parasitol Hum Comp. 1966;41(4):337 49. French.PMID: 6008534

7. Beltrame A, Zammarchi L, Zuglian G, Gobbi F, Angheben A, Marchese V, et al. Schistosomiasis screening of travelers from Italy with possible exposure in Corsica, France. Emerg Infect Dis. 2015;21(10):1887-9. DOI: 10.3201/eid2110.150869 PMID: 26401824

8. Gautret P, Mockenhaupt FP, von Sonnenburg F, Rothe C, Libman $M$, Van De Winkel K, et al. Local and International Implications of Schistosomiasis Acquired in Corsica, France. Emerg Infect Dis. 2015;21(10):1865-8. DOI: 10.3201/eid2110.150881 PMID: 26401954

9. Berry A, Paris L, Boissier J, Caumes E. Schistosomiasis screening of travelers to Corsica, France.Emerg Infect Dis. 2016;22(1):159. http://dx.doi.org/10.3201/eid2201.151290DOI: 10.1007/s00436-015-4643-4 PMID: 26268566

10. Moné H, Holtfreter MC, Allienne JF, Mintsa-Nguéma R, Ibikounlé M, Boissier J, et al. Introgressive hybridizations of Schistosoma haematobium by Schistosoma bovis at the origin of the first case report of schistosomiasis in Corsica (France, 
Europe). Parasitol Res. 2015;114(11):4127-33. DOI: 10.1007/

s00436-015-4643-4 PMID: 26268566

11. Grandière-Pérez L, Ansart $S$, Paris L, Faussart A, Jaureguiberry $\mathrm{S}$, Grivois JP, et al. Efficacy of praziquantel during the

incubation and invasive phase of Schistosoma haematobium schistosomiasis in 18 travelers. Am J Trop Med Hyg.

2006;74(5):814-8.PMID: 16687686

\section{License and copyright}

This is an open-access article distributed under the terms of the Creative Commons Attribution (CC BY 4.0) Licence. You may share and adapt the material, but must give appropriate credit to the source, provide a link to the licence, and indicate if changes were made.

This article is copyright of the authors, 2016. 